\title{
HEAVY METAL CONTAMINATION OF ROADSIDE SOIL NEAR SUN HIGHWAY IN ROMANIA
}

\author{
Alina-Maria Anghelache ${ }^{1}$, Lidia Kim ${ }^{1}$, Adriana Cuciureanu ${ }^{1}$, Gheorghe Batrinescu ${ }^{1}$, Luoana \\ Florentina Pascu ${ }^{1}$ \\ ${ }^{1}$ National Research and Development Institute for Industrial Ecology - ECOIND Bucharest, \\ Drumul Podu Dambovitei St. 71- 73, 060652, evmt@incdecoind.ro, Bucharest, Romania
}

\begin{abstract}
In order to assess the impact of car emissions on the soil, studies are required to monitor the concentation heavy metals from roadside soils. In this paper, we report an extensive survey of the roadside soils contamination with heavy metal along the Sun Highway (A2) which connects Bucharest to Constanta. The contents of heavy metals ( $\mathrm{Cd}, \mathrm{Cu}, \mathrm{Ni}, \mathrm{Pb}, \mathrm{Zn}, \mathrm{As}$ ) were assessed by inductively coupled plasma mass spectrometry (ICP-MS). The car pollution was also studied to link it with the concentrations and distributions of heavy metals in the roadside soils.A comparison between the degree of contamination obtained in the set points was made. Moreover, the impact of the metal concentration value was debated.
\end{abstract}

Keywords: contamination; heavy metals; ICP-MS; roadside soil, Romania

\section{Introduction}

Industrial growth and urbanization processes unbalanced the harmony between human beings and their natural environment [1]. During the last fifty years the world's population has undergone a significant change in its geographical distribution [2], the proportion of those living in the urban environment grew from 5\% to $50 \%$ [3]. At this rate the degree of urbanization will increase, so two-thirds of all people will live in large towns or cities by 2030 [2, 3].

The accumulation of contaminants from all human activities leads to the corruption of the ecosystem and it has a negative effect on the environment, human health and in general, on all living organisms. [3, 4]. After the 1950, when the world became mostly urban [2], the quality of the environment started to be a matter of interest.

Throughout the world the continuous industrialization and human social, economic and agricultural activities have been accompanied by the increased pollution of the soil since a wide range of contaminants from this areas affected soil quality [1, 3-5]. Due to its critical role in delivering ecosystem services soils quality and management gained a great importance $[6,7]$.

Nowadays, heavy metals pollution is the bigges threat for soil quality, negatively affecting the human health [8-10].

By definition soil consists in a mixture of weathered minerals and various amounts of organic matter. Airborne emissions from the rapidly expanding industrial areas, processed solid wastes, sludge, leaching of waste materials [10] mine tailings, disposal of high metal wastes, leaded gasoline and paints, land application of fertilizers, animal manures, sewage sludge, pesticides, wastewater irrigation, coal combustion residues, spillage of petrochemicals and atmospheric deposition [8, 11] led to the contamination by the accumulation of heavy metals and metalloids in the soil.

The scientific community classified different metals as "heavy" based on their density, atomic number or atomic weight, chemical properties or toxicity". E.g: heavy 
metals were those inorganic elements which in their standard state have a specific gravity of more than $5 \mathrm{~g} / \mathrm{cm}^{3}$ [12]. Currently there are known sixty heavy metals. The most commonly found at contaminated sites were lead $(\mathrm{Pb})$, chromium $(\mathrm{Cr})$, arsenic (As), zinc $(\mathrm{Zn})$, cadmium $(\mathrm{Cd})$, copper $(\mathrm{Cu})$, mercury $(\mathrm{Hg})$, and nickel $(\mathrm{Ni})$ [11]. In theory "normal soil" contains $200 \mathrm{~g}$ chromium, $80 \mathrm{~g}$ nickel, $16 \mathrm{~g}$ lead, $0.5 \mathrm{~g}$ mercury and $0.2 \mathrm{~g}$ cadmium per $1000 \mathrm{~kg}$ [13].

Monitoring the soil pollution with heavy metals is of interest due to their impact on groundwater and surface water as well as on plants, animals and humans [14]. Cd exposure was linked to renal, pulmonary, hepatic, skeletal, reproductive disorder or to cancer. $\mathrm{Cu}$ is an essential element that became toxic to both humans and animals when its concentration exceeds the safe limits.[15]

The current studies [10, 15-18] showed that anti-knock agents used in automotive fuel $[17,18]$ could contaminate the air and soils by their toxic emissions containing $\mathrm{Pb}, \mathrm{Cd}, \mathrm{Zn}, \mathrm{Ni}$. Also the worn out tyres, the oils leakage, the corrosion of batteries and metallic parts such as radiators increased the accumulation of these metals in roadside soil $[19,20]$

Herein we presented a study concerning the concentrations $\mathrm{Cd}, \mathrm{Cu}, \mathrm{Ni}, \mathrm{Pb}, \mathrm{Zn}$ and As in soils along the Sun Highway in Romania which connects Bucharest to Constanta. We also have correlated their concentrations with the traffic densities at each sampling site.

\section{Materials and Methods}

\subsection{Sampling site}

This study was conducted alog the Sun Highway (A2) and consisted in 15 roadside sites. The A2 motorway spans from Bucharest to Constanta (Fig. 1), with a total length of about $204 \mathrm{~km}$, starting in Bucharest and ending in the intersection with the bypass road of Constanta.

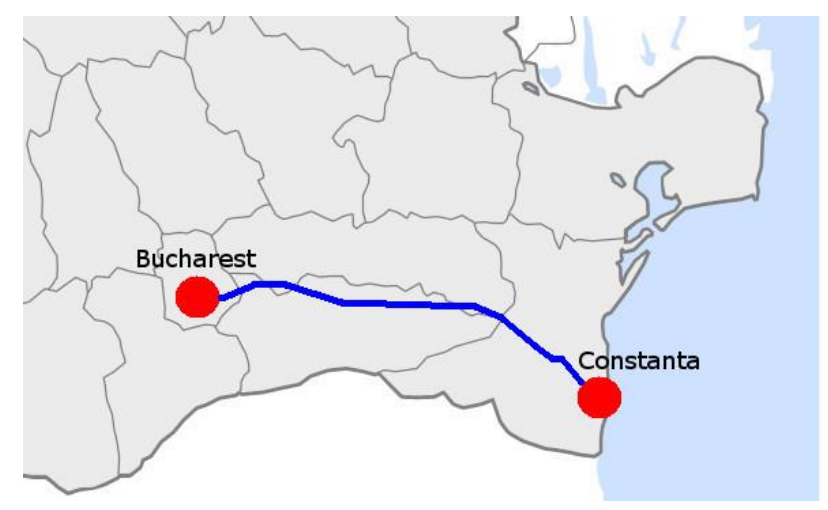

Figure 1: Sun Highway (A2)

In 2010 A2 was included among the most traveled ten roads in the country with a total throughput higher than 64,000 vehicles in 24 hours. The section with the most traffic was between Fundulea and Lehliu, in one day nearly 20,000 vehicles transiting the area.

Bucharest - Fundulea - Lehliu - Drajna section was opened to traffic in 2004, while Drajna - Fetesti section was commissioned in 2007. Fetesti - Cernavoda section was built in 1987 and rehabilitated in 2008. In the summer of 2009 were opened the first gas stations. 
Along the route there are two important bridges across the Danube (i.e. over Borcea branch of the Danube) and a toll booth station where the road tax is collected.

\subsection{Legislation in force in Romania regarding soil and soil pollution}

In the romanian MAPPM order no. 756/97 - Regulations concerning the assessment of environmental pollution [21] are set the benchmarks for traces of chemical elements in soil. Also The normal values, the alert and intervention threshold are also established.

\begin{tabular}{|c|c|c|c|}
\hline \multicolumn{4}{|c|}{ MAPPM order no. 756/97: Benchmarks for traces of chemical elements in soil } \\
\hline $\begin{array}{c}\text { Chemical } \\
\text { element }\end{array}$ & $\begin{array}{c}\text { Normal values } \\
\text { (mg/kgds) }\end{array}$ & $\begin{array}{c}\text { Alert threshold } \\
\text { (mg/kgds) }\end{array}$ & $\begin{array}{c}\text { Intervention threshold } \\
\text { (mg/kgds) }\end{array}$ \\
\hline $\mathrm{Cd}$ & 1 & 3 & 5 \\
\hline $\mathrm{Cu}$ & 20 & 100 & 200 \\
\hline $\mathrm{Ni}$ & 20 & 75 & 150 \\
\hline $\mathrm{Pb}$ & 20 & 50 & 100 \\
\hline $\mathrm{Zn}$ & 100 & 300 & 600 \\
\hline $\mathrm{As}$ & 5 & 15 & 25 \\
\hline
\end{tabular}

In Chapter II: Road management, Section I from the romanian Government Ordinance no. 43/1997 concerning the roads status [22] were established definitions for the following terms: road reservation (footprint), safety zones and protection zones.

The road reservation was defined as the land area occupied by the constructive elements of the road: carriageway, footpaths, cycle lanes, shoulders, ditches, culverts, embankments, ditches, retaining walls and other works of art.

The safety zones were land areas situated on both sides of the road footprint that were intended exclusively for road signs, road plantation or other purposes related to the maintenance and exploitation of the road, ensuring the traffic safety or protection of the owners. Depending on the type of road, these safety areas extended from the outer limit of the road footprint to:

- $1.5 \mathrm{~m}$ from the outer edge of ditches when the road was located on the ground level;

- $2 \mathrm{~m}$ from the foot slope in case of embankment roads;

- $3 \mathrm{~m}$ from the top edge of the slope in case of excavation roads with a height up to 5 $m$ including;

- $5 \mathrm{~m}$ from the top edge of the slope in case of excavation roads with a height over 5 $\mathrm{m}$.

The safety zones were defined also for bridge areas as follows:

- $10 \mathrm{~m}$ from the outer limit of the point where the bridge connects with embankment in case of bridges without defense works (the access ramp is part of the bridge);

- at the outer limit of the riverbank protection works in case of bridges with protections longer than $10 \mathrm{~m}$ (the access ramp is part of the bridge).

The land areas necessary for protection and further development of the road that were located on both sides of the safety zones are the so-called protection zones. Depending on the road type these protection zones extended between the outer edges of safety areas and the road edges, being delimitated as follows:

- highways - $50 \mathrm{~m}$ from the road axis to outer edge of the road; 
- national roads - $22 \mathrm{~m}$ from the road axis to outer edge of the road;

- county roads $-20 \mathrm{~m}$ from the road axis to outer edge of the road;

- local roads $-18 \mathrm{~m}$ from the road axis to outer edge of the road.

\subsection{Collection of soil samples}

In order to assess the soil pollution near the A2 motorway, there were established 15 pedological points located in key areas such as the entrance and exit of the highway (where traffic is particularly intense), near parking and gas stations, near designated circulation paths crossing the highway and also near parts lacking any special arrangement.

The soil sampling campaign from the safety area of A2 highway was carried out in the month of August 2015 using a Buerkle soil sampler. On each site average sample soils $(S)$ were taken at three different distances $(1 \mathrm{~m}, 3 \mathrm{~m}$ and $5 \mathrm{~m})$ from the road reservation. For the distances of $1 \mathrm{~m}$ and $3 \mathrm{~m}$ toward the road footprint were collected 30 soil samples ( $\mathrm{S} 1 \div \mathrm{S} 15)$ from the established pedological points, and only 7 (S1:S6; and S9) for the $5 \mathrm{~m}$ distance.

In order to have benchmarks in our study, two soil blank samples were collected from the soil considered to be unaffected by the road traffic which was located at $60 \mathrm{~m}$ toward the safety zones. For both directions Bucharest - Constanta and Constanta - Bucharest the soil samples were collected from similar points.

Table 1. Sampling points description: Direction Bucharest - Constanta

\begin{tabular}{|c|c|}
\hline $\begin{array}{c}\text { Soil } \\
\text { sample }\end{array}$ & Description of the sampling points \\
\hline $\mathrm{S}^{*}$ & - sampling point km 12 located near the highway in the safety area \\
\hline S2 & - sampling point km 48 located near the highway next to the service area \\
\hline S3 & - sampling point km 74 located near the highway next to the service area \\
\hline S4 & - sampling point km 90 located near the highway in the safety area \\
\hline S5 & - sampling point km 120 located near the highway next to the service area \\
\hline S6 & - sampling point km 142 located near the highway in the safety area \\
\hline S7 & - sampling point km 160 located near the highway in the safety area \\
\hline S8 & - sampling point km 196 located near the highway in the safety area \\
\hline S8-M $\mathrm{M}^{\star *}$ & $\begin{array}{l}\text { - sampling point km } 196 \text { located near the highway at approximately } 60 \mathrm{~m} \text { toward } \\
\text { the safety area }\end{array}$ \\
\hline
\end{tabular}

Table 2. Sampling points description: Direction Constanta - Bucharest

\begin{tabular}{|c|l|}
\hline $\begin{array}{c}\text { Soil } \\
\text { sample }\end{array}$ & \multicolumn{1}{c|}{ Description of the sampling points } \\
\hline $\mathrm{S} 9$ & - sampling point $\mathrm{km} 205$ located near the highway next to the service area \\
\hline $\mathrm{S} 10$ & - sampling point $\mathrm{km} 196$ located near the highway in the safety area \\
\hline $\mathrm{S} 10-\mathrm{M}^{* *}$ & $\begin{array}{l}\text { - sampling point } \mathrm{km} 196 \text { located near the highway at approximately } 60 \mathrm{~m} \text { toward } \\
\text { the safety area }\end{array}$ \\
\hline $\mathrm{S} 11$ & - sampling point $\mathrm{km} \mathrm{160} \mathrm{located} \mathrm{near} \mathrm{the} \mathrm{highway} \mathrm{in} \mathrm{the} \mathrm{safety} \mathrm{area}$ \\
\hline $\mathrm{S} 12$ & - sampling point $\mathrm{km} \mathrm{120} \mathrm{located} \mathrm{near} \mathrm{the} \mathrm{highway} \mathrm{next} \mathrm{to} \mathrm{the} \mathrm{service} \mathrm{area}$ \\
\hline $\mathrm{S} 13$ & - sampling point $\mathrm{km} 74$ located near the highway next to the service area \\
\hline $\mathrm{S} 14$ & - sampling point $\mathrm{km} 48$ located near the highway next to the service area \\
\hline $\mathrm{S} 15$ & - sampling point $\mathrm{km} \mathrm{12} \mathrm{located} \mathrm{near} \mathrm{the} \mathrm{highway} \mathrm{in} \mathrm{the} \mathrm{safety} \mathrm{area}$ \\
\hline
\end{tabular}




\subsection{Sample soil preparation}

Prior to analysis, in the laboratory, soil samples were air dried at ambient temperature $\left(22-25^{\circ} \mathrm{C}\right)$, crushed manually in a porcelain mortar, and sieved through a $2-\mathrm{mm}$ plastic screen. The fraction $<150 \mu \mathrm{m}$ was retained due to its better homogeneity, decreasing the standard deviation repeatability during the analysis.

In order to mineralise the samples about $2 \mathrm{~g}$ of dried soil were placed in a 100 $\mathrm{mL}$ beaker with $30 \mathrm{~mL}$ mixture of concentrated nitric and hydrochloric acid $(3: 1 \mathrm{v} / \mathrm{v})$ and heated. After proper digestion, the digest was filtered and washed with deionised water until made up to $50 \mathrm{ml}[21,22]$.

\section{Results and Discussion}

Heavy metal analysis of the soil samples was carried out through inductively coupled plasma mass spectrometry (ICP-MS) using an ICP-MS instrument Aurora M90 model by Bruker. The metal concentration was determined against a calibration curve plotted in the range $10 \mu \mathrm{g} / \mathrm{L}-50 \mu \mathrm{g} / \mathrm{L}$ and built with five concentrations each of $\mathrm{Cd}, \mathrm{Cu}, \mathrm{Ni}, \mathrm{Pb}, \mathrm{Zn}$ and $\mathrm{As}$ prepared from their respective stock solutions. The calibration curve the solutions obtained after soil mineralization were diluted to fit in the concentration range of the analysis.

Thus the heavy metal concentration of $\mathrm{Cd}, \mathrm{Cu}, \mathrm{Ni}, \mathrm{Pb}, \mathrm{Zn}$ and $\mathrm{As}$ in the unknown soil samples collected was automatically determined through ICP-MS

Table 3: Heavy metal concentration ( $\mathrm{mg} / \mathrm{kg} \mathrm{ds}$ ) of roadside

\begin{tabular}{|c|c|c|c|c|c|c|c|c|}
\hline Sample code & Distance (m) & $\mathrm{pH}$ & Cd & $\mathrm{Cu}$ & $\mathrm{Ni}$ & $\mathrm{Pb}$ & $\mathrm{Zn}$ & As \\
\hline \multirow{3}{*}{ S1 } & 1 & 7.92 & $2.62^{*}$ & 46.36 & 23.49 & 125.57 & 113.70 & 6.37 \\
\hline & 3 & 8.34 & 3.37 & 23.89 & 25.74 & $57.92^{* *}$ & 110.89 & 5.94 \\
\hline & 5 & 7.56 & 2.91 & 10.80 & 23.43 & 29.20 & 52.63 & 5.40 \\
\hline \multirow{3}{*}{ S2 } & 1 & 7.82 & 0.37 & 31.75 & 24.88 & 77.59 & 125.88 & 3.92 \\
\hline & 3 & 8.35 & 0.63 & 15.89 & 32.41 & 30.65 & 77.69 & 4.41 \\
\hline & 5 & 7.98 & 0.38 & 14.35 & 34.12 & 28.07 & 72.13 & 4.78 \\
\hline \multirow{3}{*}{ S3 } & 1 & 8.34 & 1.49 & 16.28 & 38.89 & 29.20 & 65.24 & 2.24 \\
\hline & 3 & 8.07 & 1.65 & 13.48 & 38.52 & 31.28 & 57.21 & 3.18 \\
\hline & 5 & 8.46 & 1.39 & 12.66 & 36.97 & 29.88 & 53.18 & 3.93 \\
\hline \multirow{3}{*}{ S4 } & 1 & 8.35 & 1.98 & 7.78 & 29.03 & 24.71 & 72.64 & 5.68 \\
\hline & 3 & 7.29 & 1.85 & 11.62 & 35.23 & 26.21 & 52.04 & 5.44 \\
\hline & 5 & 7.08 & 2.22 & 12.07 & 35.34 & 27.83 & 56.16 & 5.91 \\
\hline \multirow{3}{*}{ S5 } & 1 & 8.10 & 2.70 & 18.44 & 38.55 & 27.72 & 70.02 & 5.29 \\
\hline & 3 & 8.08 & 2.28 & 32.39 & 64.64 & 39.12 & 98.93 & 5.08 \\
\hline & 5 & 8.09 & 1.13 & 19.74 & 36.21 & 27.41 & 55.94 & 4.78 \\
\hline \multirow{3}{*}{ S6 } & 1 & 7.94 & 0.61 & 16.96 & 37.49 & 30.73 & 59.49 & 2.58 \\
\hline & 3 & 8.35 & 0.25 & 16.98 & 36.88 & 29.91 & 55.76 & 2.28 \\
\hline & 5 & 8.21 & 1.02 & 14.02 & 36.45 & 30.21 & 48.69 & 2.17 \\
\hline \multirow{2}{*}{ S7 } & 1 & 7.54 & 0.77 & 15.18 & 30.10 & 47.81 & 51.61 & 3.16 \\
\hline & 3 & 8.19 & 1.13 & 14.76 & 34.81 & 33.55 & 43.76 & 3.66 \\
\hline
\end{tabular}




\begin{tabular}{|c|c|c|c|c|c|c|c|c|}
\hline \multirow{3}{*}{ S8 } & 1 & 8.25 & 0.51 & 14.97 & $\mathbf{4 1 . 7 2}$ & $\mathbf{3 8 . 2 6}$ & 43.25 & 4.09 \\
\cline { 2 - 9 } & 3 & 7.88 & 0.37 & 13.12 & $\mathbf{3 6 . 7 5}$ & $\mathbf{3 5 . 1 4}$ & 37.61 & 3.71 \\
\cline { 2 - 9 } & $\mathbf{6 0 ^ { \star \star \star }}$ & 7.92 & 0.52 & 18.14 & $\mathbf{3 8 . 0 9}$ & $\mathbf{3 0 . 1 9}$ & 56.75 & 1.55 \\
\hline
\end{tabular}

* values written in bold correspond to heavy metal concentrations exceeding the normal range and below the alert threshold

${ }^{* *}$ values written in bold and italic correspond to heavy metal concentrations below the alert threshold $\star \star * *$ soil blank test

Table 4: Heavy metal concentration $(\mathrm{mg} / \mathrm{kg} \mathrm{ds})$ of roadside

\begin{tabular}{|c|c|c|c|c|c|c|c|c|}
\hline Sample code & Distance (m) & $\mathrm{pH}$ & Cd & $\mathrm{Cu}$ & $\mathbf{N i}$ & $\mathrm{Pb}$ & $\mathrm{Zn}$ & As \\
\hline \multirow{3}{*}{ S9 } & 1 & 8.34 & $1.41^{*}$ & 16.68 & 39.01 & 33.62 & 64.55 & 1.54 \\
\hline & 3 & 8.42 & 1.45 & 15.05 & 38.24 & 33.51 & 48.20 & 1.34 \\
\hline & 5 & 7.98 & 1.28 & 13.49 & 36.88 & 28.01 & 51.53 & 1.80 \\
\hline \multirow{3}{*}{$\mathrm{S} 10$} & 1 & 8.24 & 1.67 & 15.99 & 40.63 & 34.43 & 56.62 & 4.51 \\
\hline & 3 & 8.41 & 1.89 & 15.41 & 38.66 & 34.36 & 49.65 & 4.04 \\
\hline & $60^{\star \star \star}$ & 7.70 & 1.54 & 17.41 & 38.43 & 31.59 & 58.16 & 3.48 \\
\hline \multirow{2}{*}{$\mathrm{S} 11$} & 1 & 7.85 & 1.63 & 14.57 & 30.90 & 32.41 & 54.51 & 5.28 \\
\hline & 3 & 8.24 & 1.38 & 14.15 & 31.20 & 31.96 & 57.60 & 5.68 \\
\hline \multirow{2}{*}{$\mathrm{S} 12$} & 1 & 8.01 & 1.76 & 16.89 & 33.16 & 31.52 & 56.86 & 5.55 \\
\hline & 3 & 8.63 & 1.52 & 17.56 & 35.37 & 28.80 & 48.38 & 4.93 \\
\hline \multirow{2}{*}{$\mathrm{S} 13$} & 1 & 8.18 & 1.13 & 14.87 & 29.74 & 31.13 & 59.48 & 5.80 \\
\hline & 3 & 8.46 & 1.03 & 17.34 & 35.83 & 31.34 & 57.92 & 6.16 \\
\hline \multirow{2}{*}{$\mathrm{S} 14$} & 1 & 8.36 & 0.63 & 21.25 & 35.04 & 36.43 & 71.84 & 3.54 \\
\hline & 3 & 8.83 & 0.78 & 21.96 & 36.38 & 35.60 & 64.19 & 3.90 \\
\hline \multirow{2}{*}{ S15 } & 1 & 8.21 & 0.86 & 23.98 & 28.76 & 45.03 & 97.28 & 3.06 \\
\hline & 3 & 8.18 & 0.52 & 18.34 & 32.06 & 34.50 & 59.63 & 2.44 \\
\hline
\end{tabular}

The ICP-MS analysis revealed that the highest concentration of heavy metals was recorded in $\mathrm{S} 1$ point located near the entrance on the highway. In all the soil samples collected, the results showed that all metals exceeded the normal reference value except copper and zinc. In the soil sample originating from $1 \mathrm{~m}$ distance toward the road footprint $\mathrm{Pb}$ exceeds the intervention threshold.

In all samples analyzed $\mathrm{Ni}$ and $\mathrm{Pb}$ concentrations exceed normal reference values for soils as they are stipulated in the romanian legislation.

The $\mathrm{Zn}$ concentration was below normal reference values for soils excepting the samples collected from $\mathrm{S} 1$ point (1 $\mathrm{m}$ and $3 \mathrm{~m}$ distance toward the road footprint) and $\mathrm{S} 2$ (1 $\mathrm{m}$ distance toward the road footprint).

The As and Cd concentrations of the samples coming from S1, S4, S5, S11 and $\mathrm{S} 13$ points, respectively the $\mathrm{Cu}$ concentration of the samples coming from $\mathrm{S} 1$, S5, S14 and S15 points also exceeded the normal reference value.

The organic matter and $\mathrm{pH}$ value are factors that modify the mobility of heavy metals in roadside soils. The $\mathrm{pH}$ value fluctuates in time compared to neutral value due to intense traffic activities that lead to changes in soil $\mathrm{pH}$. For all soil samples the recorded $\mathrm{pH}$ value was greater than 7 , ranging between 7.08 and 8.63. An elevated 
value of soil $\mathrm{pH}$ enhanced metal retention, as it was recorded in all samples taken from A2 motorway.

\section{Conclusions}

Heavy metals concentration in soils collected from A2 roadside were higher as compared to normal reference values for soils stipulated in the romanian legislation.

For the soil samples originating from the nearest distance toward the road footprint from the degree of contamination was higher.

$\mathrm{Ni}$ and $\mathrm{Pb}$ concentrations exceed normal values and raise a question mark regarding their accumulation in roadside soils.

\section{References}

1. G. Demie, Analyzing soil contamination status in garage and auto mechanical workshops of Shashemane City: implication for hazardous waste management. Environmental Systems Research 4, (2015)10.1186/s40068-015-0040-3).

2. J. C. Davis, J. V. Henderson, Evidence on the political economy of the urbanization process. Journal of urban economics 53, 98-125 (2003).

3. A. J. McMichael, The urban environment and health in a world of increasing globalization: issues for developing countries. Bulletin of the World Health Organization 78, 1117-1126 (2000).

4. M. Szynkowska, A. Pawlaczyk, E. Leśniewska, T. Paryjczak, Toxic metal distribution in rural and urban soil samples affected by industry and traffic. Polish Journal of Environmental Studies 18, 1141-1150 (2009).

5. M. Nita-Lazar, T. Galaon, A. Banciu, I. Paun, C. Stoica, I. Lucaciu, Screening of various harmful compounds in a new bacterial biological model. Journal of Environmental Protection and Ecology 17, 237-247 (2016).

6. S. Naeem, F. Chapin III, R. Costanza, P. R. Ehrlich, F. B. Golley, D. U. Hooper, J. H. Lawton, R. V. O’Neill, H. A. Mooney, O. E. Sala, Biodiversity and ecosystem functioning: maintaining natural life support processes. Issues in ecology 4, (1999).

7. P. Smith, M. R. Ashmore, H. I. J. Black, P. J. Burgess, C. D. Evans, T. A. Quine, A. M. Thomson, K. Hicks, H. G. Orr, D. Angeler, REVIEW: The role of ecosystems and their management in regulating climate, and soil, water and air quality. Journal of Applied Ecology 50, 812-829 (2013)10.1111/1365-2664.12016).

8. R. A. Wuana, F. E. Okieimen, Heavy Metals in Contaminated Soils: A Review of Sources, Chemistry, Risks and Best Available Strategies for Remediation. ISRN Ecology 2011, 1-20 (2011)10.5402/2011/402647).

9. A. Meche, M. C. Martins, B. E. Lofrano, C. J. Hardaway, M. Merchant, L. Verdade, Determination of heavy metals by inductively coupled plasma-optical emission spectrometry in fish from the Piracicaba River in Southern Brazil. Microchemical Journal 94, 171-174 (2010).

10. N. Buachoon, Determination of the Content of Hazardous Heavy Metals on Lycopersicon Esculentum Mill. Grown around a Contaminated Area. International Journal of Environmental Science and Development 6, 170-173 (2015)10.7763/ijesd.2015.v6.583).

11. C. R. Evanko, D. A. Dzombak, Remediation of metals-contaminated soils and groundwater. (Ground-water remediation technologies analysis center, 1997).

12. B. Sharma, S. Singh, N. J. Siddiqi, Biomedical implications of heavy metals induced imbalances in redox systems. BioMed research international 2014, 640754 (2014)10.1155/2014/640754). 
13. I. Suciu, C. Cosma, M. Todică, S. D. Bolboacă, L. Jäntschi, Analysis of soil heavy metal pollution and pattern in Central Transylvania. International journal of molecular sciences 9, 434-453 (2008).

14. M. O. Isinkaye, Distribution of heavy metals and natural radionuclides in selected mechanized agricultural farmlands within Ekiti State, Nigeria. Arabian Journal for Science and Engineering 37, 1483-1490 (2012).

15. S. Bakirdere, M. Yaman, Determination of lead, cadmium and copper in roadside soil and plants in Elazig, Turkey. Environmental monitoring and assessment 136, 401-410 (2008); published online EpubJan (10.1007/s10661-007-9695-1).

16. J. Aslam, S. A. Khan, S. H. Khan, Heavy metals contamination in roadside soil near different traffic signals in Dubai, United Arab Emirates. Journal of Saudi Chemical Society 17, 315-319 (2013)10.1016/j.jscs.2011.04.015).

17. S. M. Nakayama, Y. Ikenaka, K. Hamada, K. Muzandu, K. Choongo, H. Teraoka, N. Mizuno, M. Ishizuka, Metal and metalloid contamination in roadside soil and wild rats around a $\mathrm{Pb}-\mathrm{Zn}$ mine in Kabwe, Zambia. Environmental pollution 159, 175-181 (2011); published online EpubJan (10.1016/j.envpol.2010.09.007).

18. H. M. Naser, S. Sultana, R. Gomes, S. Noor, Heavy metal pollution of soil and vegetable grown near roadside at Gazipur. Bangladesh Journal of Agricultural Research 37, 9-17 (2012).

19. E. Abechi, O. Okunola, S. Zubairu, A. Usman, E. Apene, Evaluation of heavy metals in roadside soils of major streets in Jos metropolis, Nigeria. Journal of Environmental chemistry and Ecotoxicology 2, 98-102 (2010).

20. F. ÇELENK, T. KIZILOĞLU, Distribution of Lead Accumulation in Roadside Soils: A Case Study from D 100 Highway in Sakarya, Turkey. International Journal 1, (2015).

21. P. S. P. M. MINISTERUL APELOR, Ordinul MAPPM nr. 756/97 - Reglementari privind evaluarea poluarii mediului. (1997).

22. G. ROMANIEI, ORDONANTA GUVERNULUI Nr. 43/1997 privind regimul drumurilor. (1997).

23. B. STANDARD, BS 7755-3.9:1995 - Soil quality. Chemical methods. Extraction of trace elements soluble in aqua regia. (1995).

24. A. d. S. d. România, SR ISO 11466/99 - Calitatea solului. Extractia microelementelor solubile in apa regala. (1999). 